\title{
Aqueous Extracts of the Castor Beans as a Corrosion Inhibitor of Mild Steel in HCl Media
}

\author{
Carolina A. Santana, ${ }^{a}$ Jéssica N. da Cunha, ${ }^{\circledR a}$ José G. A. Rodrigues, ${ }^{a}$ \\ Jaqueline Greco-Duarte, ${ }^{a}$ Denise M. G. Freire ${ }^{a}$ and Eliane D'Elia ${ }^{\circledR} * a$ \\ ${ }^{a}$ Instituto de Química, Universidade Federal do Rio de Janeiro, Cidade Universitária, \\ 21941-909 Rio de Janeiro-RJ, Brazil
}

\begin{abstract}
The present work studied aqueous extracts of castor beans as a natural inhibitor of the corrosion of mild steel in $1 \mathrm{M} \mathrm{HCl}$ using gravimetric tests, potentiodynamic polarization curves, linear polarization method, electrochemical impedance measurements, surface analysis by scanning electron microscopy (SEM) and chemical characterization by Fourier transform infrared spectroscopy (FTIR). Gravimetric tests showed that inhibition efficiency (IE) increased with immersion time and concentration of the extract, reaching $97.8 \%$ in the presence of $800 \mathrm{mg} \mathrm{L}^{-1}$ inhibitor after $24 \mathrm{~h}$ immersion time. For the gravimetric tests varying the temperature, a decrease of the activation energy $\left(\mathrm{E}_{\mathrm{a}}\right)$ was observed, suggesting chemical adsorption of extract components on the metal surface. The extracts from the castor beans acted as a good corrosion inhibitor, and the macromolecules present in the high molecular weight fraction (HMWF) have a fundamental participation in this process since it presented $93.7 \%$ of IE for $200 \mathrm{mg} \mathrm{L}^{-1}$.
\end{abstract}

Keywords: mild steel, corrosion inhibitor, castor beans, natural products

\section{Introduction}

The use of corrosion inhibitors is one of the most effective ways of retarding corrosion, which is why industries apply them to protect equipment, industrial plants, and refrigeration systems in the production, transport, and storage of oil and natural gas. ${ }^{1}$ The natural inhibitors have been gaining greater expressiveness, since they come from renewable resources and vast availability, besides being biodegradable, of low cost and not harmful to the environment. ${ }^{2,3}$

Several studies ${ }^{1-26}$ were carried out to investigate the retardation of corrosion on different metals using natural inhibitors. Research related to inhibitors of natural sources such as leaves, stems, fruits, plant seeds and food residues have shown a high efficiency of inhibition of corrosion for different metals and corrosive media. ${ }^{15}$ Table 1 gives a comparison of the inhibition efficiency (IE) of different extracts from natural sources towards mild steel acid corrosion. Good inhibition efficiencies can be achieved, reaching 98\% for corrosion of carbon steel in $\mathrm{HCl}$ solution using the garlic peel and sunflower bean hull extract. ${ }^{5-22}$

*e-mail: eliane@iq.ufrj.br
About the garlic peel extract, the authors ${ }^{22}$ suggested based on headspace solid-phase microextraction-gas chromatography (HS-SPME-GC) analysis of the extract that sulfur compounds may play an important role in the inhibition process. In the sunflower bean hull study, ${ }^{5}$ the authors suggest a complex between the functional groups present in the extract molecules (fatty acid, phenolic acid, amino acid, furfural, xylose and anthocyanin) and $\mathrm{Fe}^{2+}$ ions as the adsorbed species responsible for the inhibitory action. In our previous works ${ }^{1,2,4,15}$ we showed that the high molecular weight fraction (HMWF) obtained from different extracts showed higher IE than their crude extracts suggesting that the macromolecules as proteins and/or polysaccharides play an important role in the inhibitory action of these extracts towards the mild steel acid corrosion.

In this sense, oil-bearing seeds could be an excellent source of compounds with anti-corrosion properties. In addition, their processing produces an immense amount of cake/bran.

Brazil has a variety of oleaginous in its extension, such as oil palm, castor bean, soybean, cotton, which have chemical compositions propitious to incorporate, even in part, the biodiesel. Besides, they generally present high levels of proteins and carbohydrates, organic compounds 
Table 1. Inhibition efficiencies (IE) for some natural inhibitors towards mild steel corrosion

\begin{tabular}{lccc}
\hline Natural inhibitor & $\begin{array}{c}\text { Concentration / } \\
\left(\mathrm{mg} \mathrm{L}^{-1}\right)\end{array}$ & IE / \% & Reference \\
\hline Coffee husk & 400 & 84.1 & 1 \\
Papaya seed & 1000 & 93.0 & 4 \\
Biomass of microalgae & 800 & 96.4 & 2 \\
Spirulina maxima & 400 & 98.0 & 5 \\
Sunflower bean hull & 400 & 95.0 & 10 \\
Orange peel & 500 & 90.0 & 10 \\
Passion fruit peel & 600 & 91.0 & 10 \\
Mango peel & 800 & 80.0 & 10 \\
Cashew peel & 1110 & 81.0 & 14 \\
Castor bark powder & 800 & 90.8 & 15 \\
Gorse & 800 & 95.8 & 19 \\
Henna leaves & $3 \% \mathrm{v} / \mathrm{v}$ & 83.0 & 20 \\
Grape pomace & 2000 & 93.8 & 21 \\
Papaya leaves & 400 & 98.0 & 22 \\
Garlic peel & 1000 & 85.0 & 23 \\
Potato peel & 840 & 94.2 & 24 \\
Barley & 700 & 92.5 & 25 \\
Waste of lychee fruit & 400 & 94.1 & 26 \\
Brown onion peel & & &
\end{tabular}

rich in oxygen and nitrogen, elements usually responsible for corrosion inhibition. ${ }^{27}$

"Mamona" (Ricinus communis) is a plant in the family Euphorbiaceae, whose main commercial product is the castor oil. ${ }^{27}$ This raw material can be applied in paints, varnishes, lubricants and cosmetics. ${ }^{28}$

Besides oil, castor beans have high protein levels. Severino $^{29}$ reported that depending on the oil content in the bean, the percentage of proteins can be altered. Machado et al..$^{30}$ investigated whether post-harvest storage time and fruit position in the plant interfered with their chemical characteristics. The results showed that regardless of the type of seed analyzed, protein levels do not change significantly and are relatively high.

Sathiyanathan et al. ${ }^{31}$ applied an ethanolic extract of castor leaves as a carbon steel inhibitor in $\mathrm{NaCl}$ solution. Through gravimetric and electrochemical tests, they concluded that the substrate acted as a mixed inhibitor, reaching an efficiency of $84 \%$ for $300 \mathrm{mg} \mathrm{L}^{-1}$ of extract. Abdulwahab et al. ${ }^{13}$ tested the castor oil to inhibit the corrosion of an aluminum alloy in solutions of $\mathrm{HCl}$ and $\mathrm{H}_{3} \mathrm{PO}_{4}(2 \mathrm{M})$. The electrochemical tests showed that the protection in the $\mathrm{H}_{3} \mathrm{PO}_{4}$ medium was more effective, forming a passivating film originated by the fatty acids present in the oil.
Santos et al. ${ }^{14}$ examined the effect of castor bark powder on the corrosion of 1020 carbon steel in $0.5 \mathrm{M} \mathrm{HCl}$. Inhibition efficiency varied from 65 to $83 \%$, and it was determined by gravimetric and electrochemical tests. The adsorption of the powder components on the metal surface followed the Langmuir isotherm. The authors calculated the Gibbs standard free energy of adsorption $\left(\Delta \mathrm{G}_{\text {ads }}^{\circ}\right)$ as being $-16.92 \mathrm{~kJ} \mathrm{~mol}^{-1}$ and concluded that the interaction between the molecules of the castor bark powder and the metal surface was physical. The Fourier transform infrared spectroscopy (FTIR) analyses indicated the presence of $\mathrm{C}, \mathrm{N}$ and $\mathrm{O}$ heteroatoms, incorporated in functional groups mainly related to the presence of carboxylic acids, like ricinoleic acid, which could be responsible for the inhibitory properties of the powder.

About the $\Delta \mathrm{G}^{\circ}$ ads calculation performed by Santos et al. ${ }^{14}$ in our previous works, ${ }^{1,2,10-12}$ we have shown that the determination of thermodynamic parameters such as $\Delta \mathrm{G}^{\circ}$ ads was not possible, even when placing the water concentration in $\mathrm{mg} \mathrm{L}^{-1}$, due the unknown chemical nature of the adsorbed molecules.

There is no report in literature applying aqueous extracts of castor beans (full seed) as natural corrosion inhibitors. Our main proposition would be profitable destination to cake, a residue obtained from the castor oil and biodiesel production. These seeds present high protein contents, it is assumed that they play an important role in inhibiting steel acidic corrosion. ${ }^{1,2,15}$

However, this alkaline waste (castor cake) is allergenic and toxic, due to a potent toxin, ricin protein found mainly in castor bean (Ricinus communis) endosperm. This protein $(62-66 \mathrm{kDa})$ is formed of two polypeptide chains, approximately 32 and $34 \mathrm{kDa}$, that are connected by a disulfide bond. The A chain presents inhibitory activity of ribosomes, inhibiting the protein synthesis, and the B chain has lectin function. The lethal ricin dose estimated for humans is $1-10 \mu \mathrm{g} \mathrm{kg}^{-1} .32-35$ Therefore, a high molecular weight fraction (HMWF) was tested in this work in order to eliminate the ricin toxin of the aqueous total extract and to evaluate its performance towards the corrosion inhibition process. The ricin elimination was carried out by an ultrafiltration process.

Based on that, the objective of this work is to investigate the inhibitory action of the aqueous total extract (ATE) of castor beans and its low (LMWF) and high (HMWF) molecular weight fractions towards the mild steel corrosion in $1 \mathrm{M} \mathrm{HCl}$ by gravimetric tests, potentiodynamic polarization curves, linear polarization method, electrochemical impedance measurements, surface analysis by scanning electron microscopy (SEM) and chemical characterization by FTIR. 


\section{Experimental}

Obtaining the aqueous total extract (ATE)

The castor beans were supplied by Embrapa Algodão (Campina Grande, Paraíba, Brazil) and ground. $20.0 \mathrm{~g}$ of castor beans were placed in $200 \mathrm{~mL}$ of double distilled boiling water for $2 \mathrm{~h}$ infusion. Simple filtration was performed with cotton, where the filtrate was collected and frozen at $-4{ }^{\circ} \mathrm{C}$. Finally, the frozen filtrate was lyophilized (Liotop; model L101) at an average temperature of $-52^{\circ} \mathrm{C}$, generating a powder as final product.

\section{Specimen preparation}

The chemical composition of the mild steel was (mass\%): C: $0.18, \mathrm{P}: 0.05, \mathrm{~S}: 0.05, \mathrm{Mn}: 0.30$ and the remaining percentage of $\mathrm{Fe}$.

For both gravimetric and electrochemical tests, mild steel coupons of approximately $13 \mathrm{~cm}^{2}$ were manually abraded with 100, 320 and 600 mesh water grit papers, washed with double distilled water, degreased with ethyl alcohol and then dried in hot air.

\section{Solution preparation}

All tests were performed using $1 \mathrm{M}$ hydrochloric acid solution as electrolyte, prepared using $37 \%$ hydrochloric acid from Merck Co. (Darmstadt, Germany) and double distilled water.

\section{Obtaining the high and low molecular weight fractions}

HMWF and LMWF were isolated from the total extract by diafiltration. ATE was conducted to an ultrafiltration $50 \mathrm{kDa}$ cut-off membrane (Millipore) and centrifuged at $3800 \mathrm{rpm}$ for $40 \mathrm{~min}$. The retained part was discarded to eliminate the ricin. The filtrate was poured in an ultrafiltration $3 \mathrm{kDa}$ cut-off membrane (Millipore) and submitted to centrifugation at $3800 \mathrm{rpm}$ for $40 \mathrm{~min}$. The fraction retained by this membrane (HMWF) was then washed with double distilled water and centrifuged once again. This process was repeated until the washing filtrate was colorless. The final retained part was frozen and lyophilized (HMWF). The liquid that passed through the $3 \mathrm{kDa}$ membrane, which corresponds to the LMWF was also collected, frozen and lyophilized.

\section{Gravimetric and electrochemical tests}

The gravimetric and electrochemical measurements were detailed in our previous works. ${ }^{1,2,15}$
Weight loss measurements were performed in the absence and presence of extracts containing 100, 200, 400 and $800 \mathrm{mg} \mathrm{L}^{-1}$ of inhibitor in $1 \mathrm{M} \mathrm{HCl}$ medium for different immersion times: 2, 4, 15 and $24 \mathrm{~h}$ at room temperature.

The temperature variation tests were performed at 25,35 , $45,55^{\circ} \mathrm{C}$ for $2 \mathrm{~h}$ of immersion in the absence and presence of $200 \mathrm{mg} \mathrm{L}^{-1}$ of the aqueous total extract. The weight loss measurements were obtained according to ASTM G31-7, ${ }^{36}$ using analytical balance with precision of $0.1 \mathrm{mg}$. The inhibition efficiency (IE) was obtained using equation $1 .{ }^{11}$

$\mathrm{IE}(\%)=\frac{\mathrm{C}_{\mathrm{R}, 0}-\mathrm{C}_{\mathrm{R}}}{\mathrm{C}_{\mathrm{R}, 0}} \times 100$

where, $\mathrm{C}_{\mathrm{R}, 0}$ is the corrosion rate $\left(\mathrm{g} \mathrm{cm}^{-2} \mathrm{~h}^{-1}\right)$ in the absence of the inhibitor and $C_{R}$ is the corrosion rate in the presence of the inhibitor.

The apparent activation energy of the system $\left(\mathrm{E}_{\mathrm{a}}\right)$, kinetic parameter that relates to $C_{R}$, was obtained using equation $2 .^{11}$

$\log \mathrm{C}_{\mathrm{R}}=\frac{-\mathrm{E}_{\mathrm{a}}}{2.303 \mathrm{RT}}+\log \mathrm{A}$

where, $\mathrm{E}_{\mathrm{a}}$ is the apparent activation energy $\left(\mathrm{kJ} \mathrm{mol}^{-1}\right), \mathrm{A}$ is the pre-exponential factor, $\mathrm{T}$ is the absolute temperature $(\mathrm{K})$ and $\mathrm{R}$ is the constant of ideal gases $\left(8.314 \mathrm{~J} \mathrm{~K}^{-1} \mathrm{~mol}^{-1}\right)$.

All analyses were performed in triplicate, where the Grubbs test was applied to eliminate any aberrant values, and standard deviations (SD) for the efficiencies are presented.

The electrochemical cell was composed of three electrodes: the reference electrode (saturated calomel electrode), the counter electrode (platinum wire with large area) and the working electrode (mild steel coupon with an area, exposed to the corrosive medium of $0.913 \mathrm{~cm}^{2}$ ). The electrochemical experiments were performed using an Autolab PGSTAT $128 \mathrm{~N}$ potentiostat/galvanostat, controlled by GPES 4.9 electrochemical software from Metrohm Autolab (The Netherlands).

In order to perform electrochemical impedance measurements, the open circuit potential (OCP) was first recorded as a function of time for $4000 \mathrm{~s}$ in the blank solution and for $14400 \mathrm{~s}$ in the presence of inhibitor. The impedance was made with the working electrode polarized at the OCP, in a frequency ranging from $100 \mathrm{kHz}$ to $10 \mathrm{mHz}$, with 10 points per decade and amplitude of $10 \mathrm{mV}$. The inhibition efficiency (IE) was calculated according to equation $3 .^{11}$

$\mathrm{IE}(\%)=\frac{\mathrm{R}_{\mathrm{P}}-\mathrm{R}_{\mathrm{P}, 0}}{\mathrm{R}_{\mathrm{P}}} \times 100$ 
where, $\mathrm{R}_{\mathrm{P}}$ and $\mathrm{R}_{\mathrm{P}, 0}$ are the polarization resistances $\left(\Omega \mathrm{cm}^{2}\right)$ obtained in the presence and absence of inhibitor, respectively.

The linear polarization method consisted of small variations of potential $(-30$ to $+30 \mathrm{mV})$ in relation to the $\mathrm{OCP}$, with a scanning speed of $0.6 \mathrm{~V} \mathrm{~h}^{-1}$, following the standard ASTM G59. ${ }^{37}$ The IE was calculated according to equation 3 .

Potentiodynamic anodic and cathodic polarization curves were performed using a scan rate of $1 \mathrm{mV} \mathrm{s}^{-1}$ from -300 to $+300 \mathrm{mV}$ relative to the stable open-circuit corrosion potential. Corrosion current density $\left(\mathrm{j}_{\text {corr }}\right)$, corrosion potential $\left(\mathrm{E}_{\text {corr }}\right)$, anodic $\left(\beta_{\mathrm{a}}\right)$ and cathodic $\left(\beta_{\mathrm{c}}\right)$ Tafel constants were obtained from Tafel extrapolation method.

The IE was calculated according to equation $4 .{ }^{11}$

$\operatorname{IE}(\%)=\frac{\mathrm{j}_{\text {corr }, 0}-\mathrm{j}_{\text {corr }}}{\mathrm{j}_{\text {corr }, 0}} \times 100$

where, $\mathrm{j}_{\text {corr, }, 0}$ and $\mathrm{j}_{\text {corr }}$ are the corrosion current densities $\left.(\mathrm{mA} \mathrm{cm})^{-2}\right)$ in the absence and presence of the inhibitor, respectively.

It should be noted that all the electrochemical tests were carried out with-concentrations of 25, 100, 200, 400, $800 \mathrm{mg} \mathrm{L}^{-1}$ of ATE and in $200 \mathrm{mg} \mathrm{L}^{-1}$ of LMWF and HMWF.

\section{Surface analysis by SEM}

Mild steel coupons used for surface analysis were subjected to the weight loss procedure during $2 \mathrm{~h}$ of immersion, in the absence and in the presence of $200 \mathrm{mg} \mathrm{L}^{-1}$ of the extracts (ATE and HMWF). Coupons were analyzed on a scanning electron microscope (Hitachi TM3030 Plus) and the micrographs as well as the elementary characterization through energy dispersive spectroscopy (EDS) were obtained with an acceleration voltage of $15 \mathrm{kV}$. The micrographs were obtained with a magnification of 2000x.

\section{Chemical characterization by FTIR}

The analyses were performed by spectrophotometer (Nicolet 6700) for measurements in the infrared region with Fourier transform (FTIR), operating in transmission mode range of $4000-400 \mathrm{~cm}^{-1}$ (through a conventional $\mathrm{KBr}$ pellet technique).

Sodium dodecyl sulfate polyacrylamide gel electrophoresis (SDS-PAGE) assays

For the SDS-PAGE, samples of ATE and HMWF and ricin were diluted to form solutions of $1 \mu \mathrm{g} \mu \mathrm{L}^{-1}$. The ricin standard (RS) was obtained by the fractionation of the protein extract as performed by Anandan et al..$^{38}$ Protein concentration of the solutions were determined according to Bradford's method ${ }^{39}$ using bovine serum albumin as the standard protein. Samples were combined with Laemmli's ${ }^{40}$ sample-loading buffer and submitted to boil for $5 \mathrm{~min}$ before they were applied to a $12 \%$ running and 5\% stacking PAGE polyacrylamide gels. The electrophoretic run was performed at $180 \mathrm{~V}$ at room temperature until the end of the running gel.

For the image acquisition, the gels were stained with a solution made of $40 \%$ ethanol, $10 \%$ acetic acid and $10 \%$ of a solution of $0.2 \%$ Coomassie Blue R-250 made by the dissolution of Coomassie powder in hot water and the proteins bands were visualized by destaining them with a $40 \%$ ethanol, $10 \%$ acetic acid aqueous solution.

\section{Results and Discussion}

Weight loss measurements

Weight loss measurements varying inhibitor concentration and immersion time

Table 2 presents the results of the weight loss measurements for mild steel in $1 \mathrm{M} \mathrm{HCl}$, in the absence and presence of different ATE concentrations and time immersion. In general, the increase of the extract concentration in the corrosive medium causes a decrease of the corrosion rate, which reflects in the increase of IE, explained by the formation of a protective adsorbed film, consisting of molecules of the aqueous castor bean extract, on the metal surface that is responsible for the retardation of the corrosion process.

The influence of the variables immersion time and inhibitor concentration on the IE response was studied through the complete factorial design $2^{2}$. Table 3 exhibits the combinations of the four possible experiments and the levels used for each variable, and the Table 4 exhibits the calculated effects values for the variables. Figure 1 shows the level curve, illustrating the behavior of IE in function of the variation of the immersion time and the extract concentration.

Table 4 indicates that the individual effect and the interaction $\left(b_{12}\right)$ are significant. We consider significant all the effects and interactions that do not have the value 0 in the confidence interval. ${ }^{41}$ The positive individual effects values show that the increase immersion time or extract concentration is accompanied of an increase in IE values, where the time effect is more important than the concentration. The negative effect in the interaction 
Table 2. Weight loss measurements of mild steel by varying aqueous castor bean extract concentration and immersion time

\begin{tabular}{|c|c|c|c|}
\hline time / h & $\begin{array}{c}{[\text { Extract] / }} \\
\left(\mathrm{mg} \mathrm{L}^{-1}\right)\end{array}$ & $\begin{array}{c}\mathrm{C}_{\mathrm{R}} / \\
\left(\mathrm{g} \mathrm{cm}^{-2} \mathrm{~h}^{-1}\right)\end{array}$ & $\mathrm{IE} \pm \mathrm{SD}_{\mathrm{IE}} / \%$ \\
\hline \multirow{5}{*}{2} & 0 & $1.59 \times 10^{-3}$ & - \\
\hline & 100 & $1.69 \times 10^{-4}$ & $89.3 \pm 1.1$ \\
\hline & 200 & $1.55 \times 10^{-4}$ & $90.2 \pm 0.6$ \\
\hline & 400 & $1.27 \times 10^{-4}$ & $92.0 \pm 0.7$ \\
\hline & 800 & $8.85 \times 10^{-5}$ & $94.4 \pm 0.3$ \\
\hline \multirow{5}{*}{4} & 0 & $1.51 \times 10^{-3}$ & - \\
\hline & 100 & $1.25 \times 10^{-4}$ & $91.7 \pm 0.7$ \\
\hline & 200 & $1.15 \times 10^{-4}$ & $92.4 \pm 0.4$ \\
\hline & 400 & $9.65 \times 10^{-5}$ & $93.6 \pm 0.2$ \\
\hline & 800 & $7.93 \times 10^{-5}$ & $94.7 \pm 0.4$ \\
\hline \multirow{5}{*}{15} & 0 & $1.59 \times 10^{-3}$ & - \\
\hline & 100 & $5.56 \times 10^{-5}$ & $96.5 \pm 0.2$ \\
\hline & 200 & $5.06 \times 10^{-5}$ & $96.8 \pm 0.2$ \\
\hline & 400 & $4.41 \times 10^{-5}$ & $97.2 \pm 0.1$ \\
\hline & 800 & $3.69 \times 10^{-5}$ & $97.7 \pm 0.1$ \\
\hline \multirow{5}{*}{24} & 0 & $1.44 \times 10^{-3}$ & - \\
\hline & 100 & $5.17 \times 10^{-5}$ & $96.4 \pm 0.2$ \\
\hline & 200 & $4.25 \times 10^{-5}$ & $97.0 \pm 0.1$ \\
\hline & 400 & $4.03 \times 10^{-5}$ & $97.2 \pm 0.2$ \\
\hline & 800 & $3.18 \times 10^{-5}$ & $97.8 \pm 0.1$ \\
\hline
\end{tabular}

[Extract]: extract concentration; $\mathrm{C}_{\mathrm{R}}$ : corrosion rate; IE: inhibition efficiency; $\mathrm{SD}_{\mathrm{IE}}$ : standard deviation.

Table 3. Factorial planning experiment matrix

\begin{tabular}{lcc}
\hline Issue & time $\left(\mathrm{X}_{1}\right) / \mathrm{h}$ & {$\left[\right.$ Extract] $\left(\mathrm{X}_{2}\right) /\left(\mathrm{mg} \mathrm{L}^{-1}\right)$} \\
\hline 1 & $2(-1)$ & $100(-1)$ \\
2 & $24(+1)$ & $100(-1)$ \\
3 & $2(-1)$ & $800(+1)$ \\
4 & $24(+1)$ & $800(+1)$ \\
\hline
\end{tabular}

[Extract]: extract concentration.

Table 4. Results of the effects calculated for the factorial planning variables $2^{2}$

\begin{tabular}{lc}
\hline & Effect $_{\text {cal }}$ \\
\hline $\mathrm{b}_{0}$ & $95.25 \pm 0.34$ \\
$\mathrm{~b}_{1}$ & $4.01 \pm 0.34$ \\
$\mathrm{~b}_{2}$ & $2.63 \pm 0.34$ \\
$\mathrm{~b}_{12}$ & $-1.45 \pm 0.34$ \\
\hline
\end{tabular}

between the immersion time and extract concentration variables shows that even for shorter immersion times the IE is high, as displayed in Figure 1.

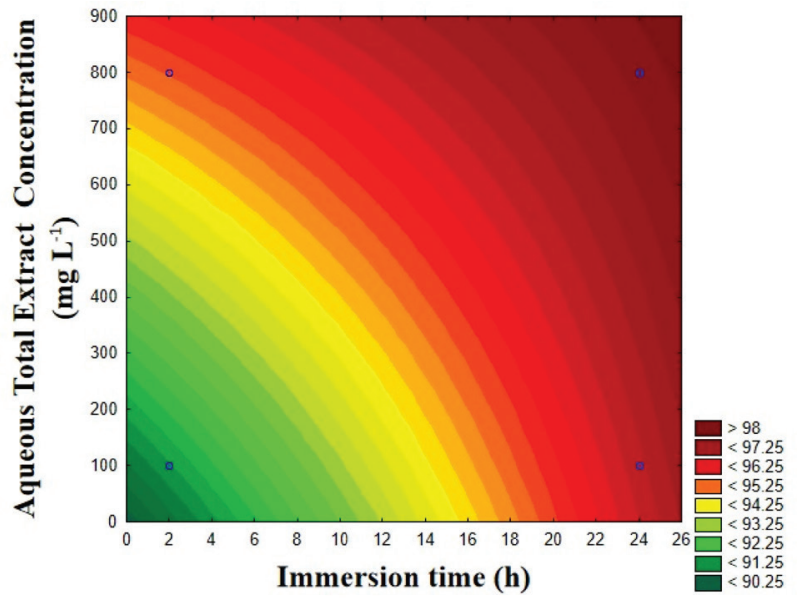

Figure 1. Level curve showing the IE behavior in function of the variation of the immersion time and the inhibitor concentration.

It is also observed an increase of IE, even if slight, both with the concentration of the extract and the immersion time, but the influence of the extract concentration becomes important in short periods of immersion.

\section{Temperature effect}

The effect of the temperature on the inhibitory action of the aqueous castor bean extract towards the mild steel corrosion in $1 \mathrm{M} \mathrm{HCl}$ solution is exposed in Table 5. In these tests, ATE concentration and immersion time were fixed at $200 \mathrm{mg} \mathrm{L}^{-1}$ and $2 \mathrm{~h}$, respectively, in the temperature range of 25 to $55^{\circ} \mathrm{C}$.

Table 5. Average corrosion rates $\left(C_{R}\right)$ and their respective inhibition efficiency values and standard deviations (SD) in the absence and presence of aqueous castor bean extract at different temperatures

\begin{tabular}{lccc}
\hline Temperature / & \multicolumn{2}{c}{$\mathrm{C}_{\mathrm{R}} /\left(\mathrm{g} \mathrm{cm}^{-2} \mathrm{~h}^{-1}\right)$} & \multirow{2}{*}{$\mathrm{IE} \pm \mathrm{SD}_{\mathrm{IE}} / \%$} \\
\cline { 2 - 3 }${ }^{\circ} \mathrm{C}$ & Blank & Extract & \\
\hline 25 & $1.85 \times 10^{-3}$ & $1.87 \times 10^{-4}$ & $89.9 \pm 0.2$ \\
35 & $3.55 \times 10^{-3}$ & $2.69 \times 10^{-4}$ & $92.4 \pm 0.2$ \\
45 & $6.12 \times 10^{-3}$ & $3.56 \times 10^{-4}$ & $94.2 \pm 0.2$ \\
55 & $1.05 \times 10^{-2}$ & $6.29 \times 10^{-4}$ & $94.0 \pm 0.1$ \\
\hline $\mathrm{C}$
\end{tabular}

$\mathrm{C}_{\mathrm{R}}$ : corrosion rate; IE: inhibition efficiency; $\mathrm{SD}_{\mathrm{IE}}$ : standard deviation.

Corrosion rates increase with temperature either in the absence or in the presence of inhibitor as the temperature increases. This increase is more important in the absence of the extract, featuring an increase of IE in the range of 25 to $45^{\circ} \mathrm{C}$, varying from 89.9 to $94.2 \%$. However, it remains basically unchanged between 45 and $55^{\circ} \mathrm{C}$, evidenced by the $\mathrm{SD}_{\mathrm{IE}}$ values, with a magnitude of $94 \%$. The results suppose that as the temperature of the solution increases, the water molecules desorption from the metal surface is favored, resulting in an increase in surface coverage by the inhibitory molecules. 
The Arrhenius curves (Figure 2) were obtained using the data presented in Table 5, where the angular coefficient of the straight line gives the apparent activation energy value $\left(\mathrm{E}_{\mathrm{a}}\right)$ associated to the mild steel corrosive process, according to the equation 2 .

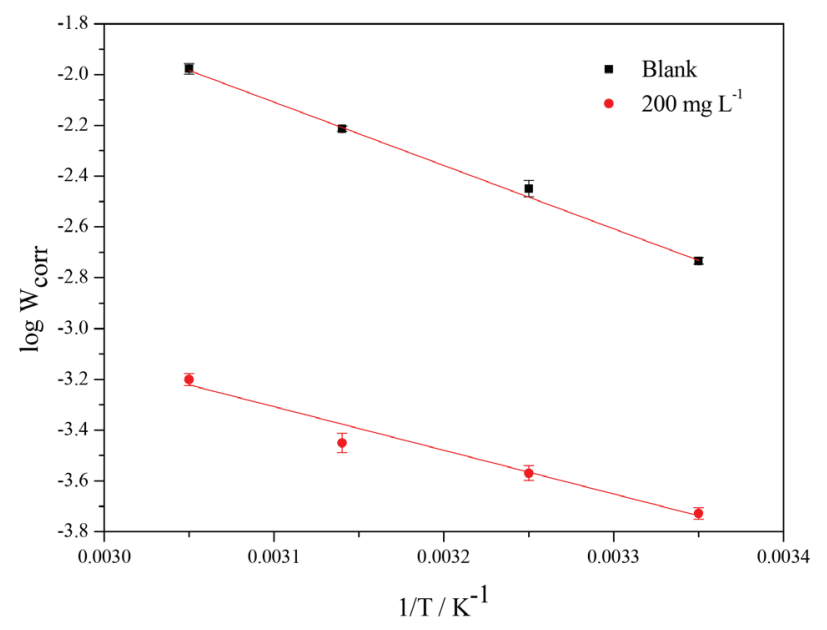

Figure 2. Arrhenius plots for mid steel in $1 \mathrm{M} \mathrm{HCl}$ solution in the absence and presence of aqueous castor bean extract.

The $\mathrm{E}_{\mathrm{a}}$ in the absence of the inhibitor was $47.3 \mathrm{~kJ} \mathrm{~mol}^{-1}$ and in the presence was $32.0 \mathrm{~kJ} \mathrm{~mol}^{-1}$. A lower value of $\mathrm{E}_{\mathrm{a}}$ was observed in the presence of inhibitor. This phenomenon could be attributed to the chemisorption involving the charge transfer from the aqueous castor beans extract molecules to the mild steel surface. This behavior is different from the one presented by Santos et al. ${ }^{14}$ where they concluded that the interaction between the molecules of the castor bark powder and the metal surface was physical due the $\Delta \mathrm{G}^{\circ}{ }_{\text {ads }}$ calculation, which is in our point of view inappropriate.

The activation parameters (enthalpy and entropy) were calculated by an alternative form of the Arrhenius equation (equation 5): ${ }^{42}$

$\mathrm{C}_{\mathrm{R}}=\frac{\mathrm{RT}}{\mathrm{Nh}} \exp \left(\frac{\Delta \mathrm{S}^{*}}{\mathrm{R}}\right) \exp \left(\frac{-\Delta \mathrm{H}^{*}}{\mathrm{RT}}\right)$

where, $\mathrm{h}$ is the Planck constant $\left(6.63 \times 10^{-34} \mathrm{~J} \mathrm{~s}\right), \mathrm{N}$ is the Avogadro number $\left(6.02 \times 10^{23}\right), \Delta \mathrm{S}^{*}$ is the activation entropy and $\Delta \mathrm{H}^{*}$ is the activation enthalpy.

The plot $\ln \left(\mathrm{C}_{\mathrm{R}} / \mathrm{T}\right)$ vs. $1 / \mathrm{T}$ produces a line with an angular coefficient of $-\Delta H^{*} / \mathrm{R}$ and a linear coefficient of $\ln (\mathrm{R} / \mathrm{Nh})+\Delta \mathrm{S}^{*} / \mathrm{R}$, from which $\Delta \mathrm{S}^{*}$ and $\Delta \mathrm{H}^{*}$ are calculated.

The positive values for the activation enthalpies, $44.7 \mathrm{~kJ} \mathrm{~mol}^{-1}$ for the blank and $29.4 \mathrm{~kJ} \mathrm{~mol}^{-1}$ for the extract, express the endothermic nature of the mild steel dissolution. As the calculated enthalpies values were lower than the activation energies, there is an indication that the corrosion process occurs through a gaseous reaction, which could be related to the hydrogen evolution in addition to a decrease in the total volume of the reaction. The difference $E_{a}-\Delta H$ is equal to RT $\left(2.6 \mathrm{~kJ} \mathrm{~mol}^{-1}\right)$, suggesting that the metal dissolution is a unimolecular reaction. ${ }^{43}$ The negative values of $\Delta \mathrm{S}^{*}$ in the absence $\left(-89.8 \mathrm{~J} \mathrm{~mol}^{-1} \mathrm{~K}^{-1}\right)$ and presence $\left(-160.5 \mathrm{~J} \mathrm{~mol}^{-1} \mathrm{~K}^{-1}\right)$ of the extract indicate a step of association of the activated complex in the determinant step.

\section{Electrochemical measurements}

\section{Open circuit potential}

The stabilized open-circuit potential (OCP) was measured after $4000 \mathrm{~s}$ of exposure for the blank and $14400 \mathrm{~s}$ for the aqueous castor beans extracts solutions (ATE, HMWF and LMWF). Figure 3a shows the mild steel OCP values in $1 \mathrm{M} \mathrm{HCl}$ solution without extract for $4000 \mathrm{~s}$. The OCP increases in the first $400 \mathrm{~s}$ and then decreases quickly due to the dissolution process of the air formed oxide film and the attack on the mild steel surface. ${ }^{44}$

Figures $3 \mathrm{a}$ and $3 \mathrm{~b}$ show that, regardless the situation, all the curves maintain a characteristic profile: abrupt variation of potential in the first minutes of immersion, with an increase of value and stabilization towards positive values in the presence of the extract, which varied little in the concentration range of 100 to $800 \mathrm{mg} \mathrm{L}^{-1}$ ( -495 to $-494 \mathrm{mV}$, respectively). Unlike curves obtained in the presence of the inhibitor, the OCP obtained for mild steel in $\mathrm{HCl}$ solution required only 4000 s to reach the stationary state at $-503 \mathrm{mV}$. In the presence of HMWF and LMWF, the OCP stabilized at -482 and $-485 \mathrm{mV}$, respectively. These variations in OCP confirm that all inhibitors (ATE, HMWF and LMWF) have mixed-type nature with low anodic character.

\section{Electrochemical impedance spectroscopy (EIS)}

Figures $4 \mathrm{a}$ and $4 \mathrm{~b}$ display the Nyquist diagrams in the absence and presence of inhibitor. It is observed the presence of a single capacitive loop for all frequency domain examined, indicating that the system is under charge transfer control, being associated with the charge transfer process and double layer capacitance. ${ }^{45}$

It is important to emphasize that all capacitive loops were depressed, which is attributed to the surface heterogeneity of solid electrodes (causing frequency dispersion), during the corrosion process. ${ }^{4,46,47}$ This also led us to choose a constant phase element (CPE) instead of a double layer capacitor data analysis.

All the diagrams were analyzed based on the equivalent circuit shown in Figure 5, where $R_{s}$ is the solution resistance, $R_{P}$ is the polarization resistance and CPE is the 

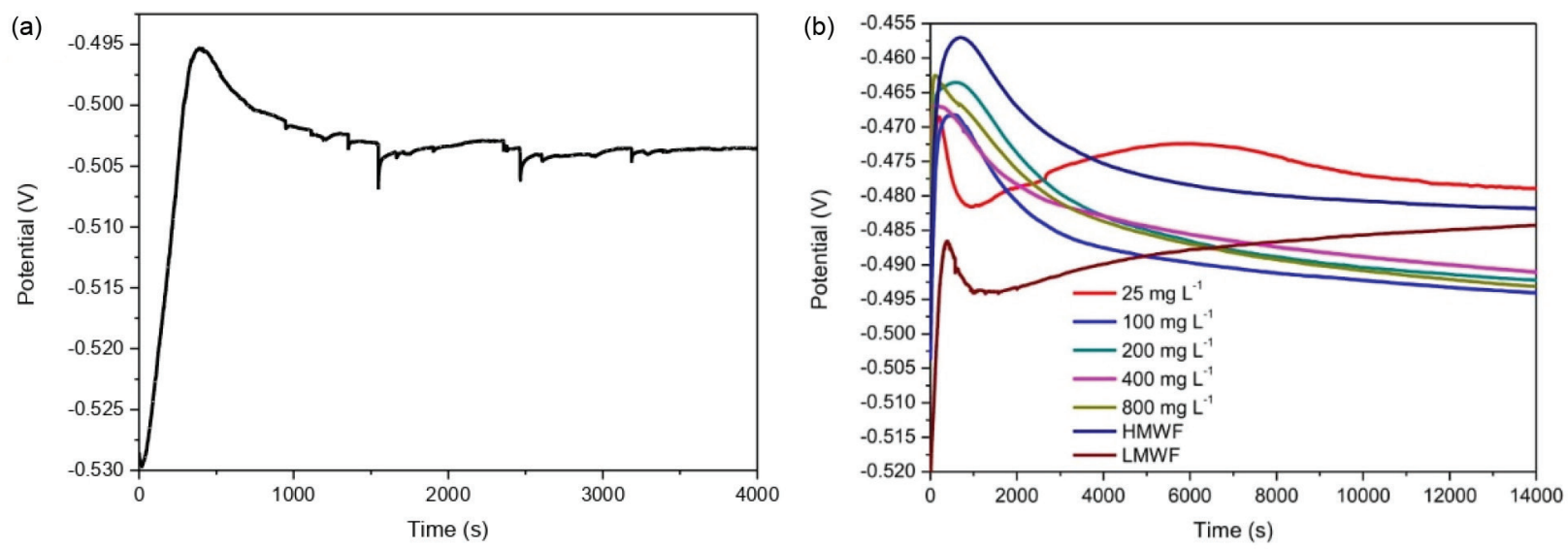

Figure 3. OCP plots for mild steel in (a) $1 \mathrm{M} \mathrm{HCl}$ and (b) in the presence of different concentrations of the aqueous castor beans extract, $\mathrm{HMWF}$ and LMWF at $200 \mathrm{mg} \mathrm{L}^{-1}$.
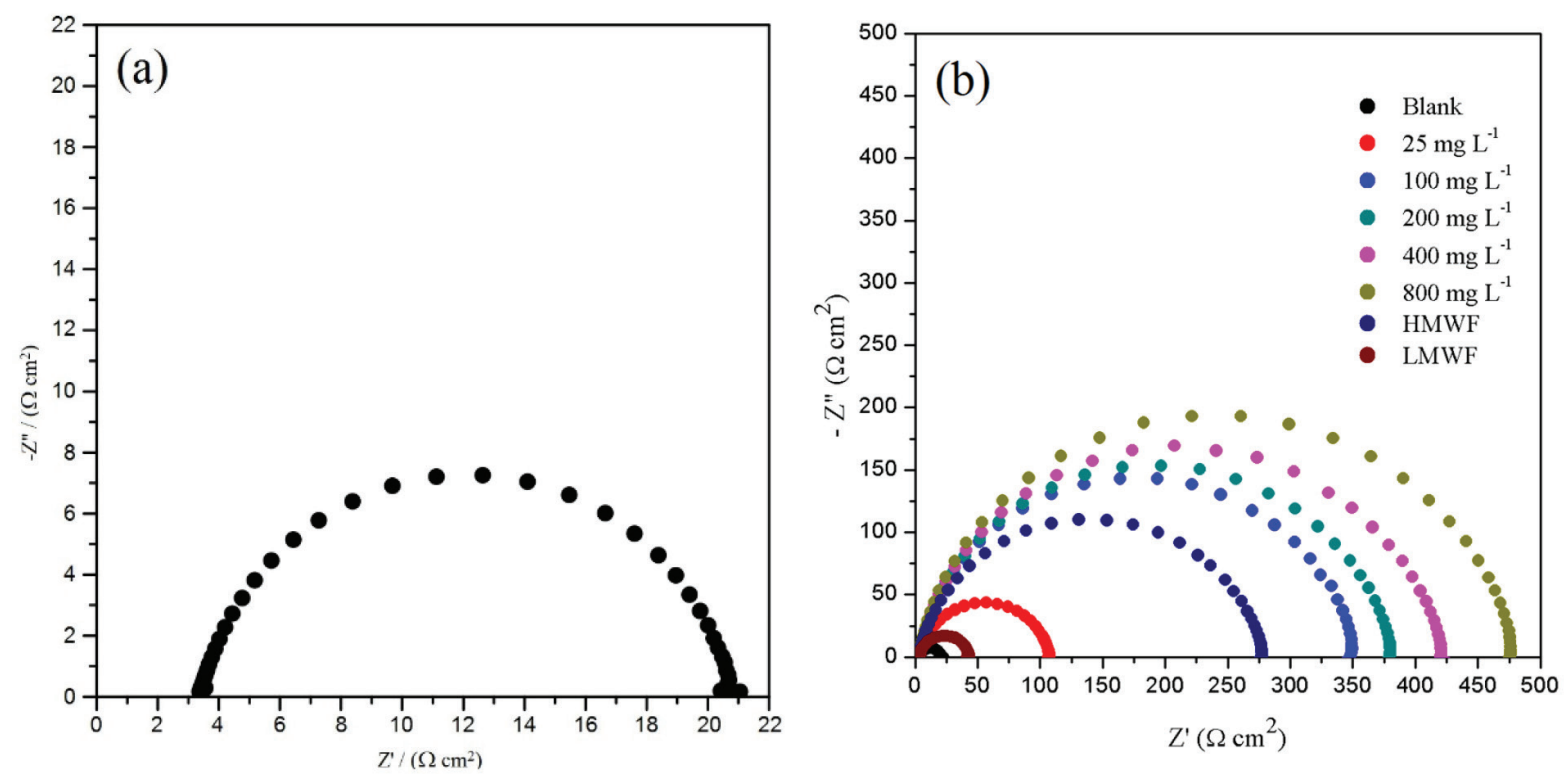

Figure 4. Nyquist diagrams for mild steel in (a) $1 \mathrm{M} \mathrm{HCl}$ and (b) in the presence of the extract in different concentrations.

constant phase element. The double layer capacitance $\left(\mathrm{C}_{\mathrm{d} 1}\right)$, for the CPE, was obtained according to the equation $6:^{1}$

$C_{d 1}=Y_{0}\left(2 \pi f_{\max }\right)^{n-1}$

where, $\mathrm{Y}_{0}$ is the magnitude of CPE, $\mathrm{n}$ represents the deviation from the ideal behavior, and $\mathrm{f}_{\max }$ is the frequency in which the imaginary component of the impedance is maximal.

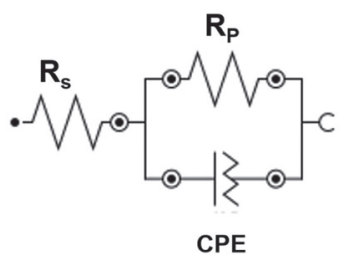

Figure 5. Equivalent circuit proposed for the interpretation of the data obtained for mild steel using the EIS technique.
Table 6 presents the parameters obtained from the electrochemical impedance diagrams at different concentrations of ATE and at $200 \mathrm{mg} \mathrm{L}^{-1}$ of HMWF and LMWF.

The addition of aqueous extract in the corrosive solution causes a progressive increase in the polarization resistance $\left(R_{P}\right)$ and a reduction in $f_{\max }$, decreasing the double layer capacitance $\left(\mathrm{C}_{\mathrm{dl}}\right)$ value, which consequently enhances IE, reaching maximum of $96.3 \%$ at $800 \mathrm{mg} \mathrm{L}^{-1}$ of ATE, which is in agreement with weight loss data. It can be seen that in the presence of HMWF, $R_{P}$ is slightly smaller than $R_{P}$ obtained from ATE at $200 \mathrm{mg} \mathrm{L}^{-1}$; however, the value remains high, proving that the concentration of macromolecules in the range of 3 to $50 \mathrm{kDa}$ was not enough to compromise the inhibition efficiency $(\mathrm{IE}=93.7 \%)$. The enhancement in the polarization resistance $\left(R_{P}\right)$ and diminishment in $f_{\max }$ for ATE and HMWF assays demonstrate that both modify 
Table 6. Electrochemical parameters obtained from the EIS technique in the absence and presence of ATE at different concentrations and at $200 \mathrm{mg} \mathrm{L}^{-1}$ of HMWF and LMWF

\begin{tabular}{|c|c|c|c|c|c|c|}
\hline$[$ Extract $] /\left(\mathrm{mg} \mathrm{L}^{-1}\right)$ & $\mathrm{f}_{\max } / \mathrm{Hz}$ & $\mathrm{R}_{\mathrm{p}} /\left(\Omega \mathrm{cm}^{2}\right)$ & $\mathrm{Y}_{0} /\left(\mu \mathrm{Mho} \mathrm{cm}^{-2}\right)$ & $\mathrm{C}_{\mathrm{dl}} /\left(\mu \mathrm{F} \mathrm{cm} \mathrm{cm}^{-2}\right)$ & $\mathrm{n}$ & $\mathrm{IE} \pm \mathrm{SD}_{\mathrm{IE}} / \%$ \\
\hline 0 & 79.4 & 17.4 & 231 & 107 & 0.876 & - \\
\hline 25 & 19.9 & 104 & 137 & 74.9 & 0.875 & $83.3 \pm 1.3$ \\
\hline 100 & 12.6 & 346 & 64.5 & 39.5 & 0.888 & $95.0 \pm 0.4$ \\
\hline 200 & 10.0 & 377 & 66.1 & 40.5 & 0.882 & $95.4 \pm 0.2$ \\
\hline 400 & 10.0 & 417 & 63.2 & 38.6 & 0.881 & $95.8 \pm 0.5$ \\
\hline 800 & 10.0 & 473 & 58.5 & 36.5 & 0.886 & $96.3 \pm 0.3$ \\
\hline HMWF & 15.9 & 274 & 69.4 & 39.4 & 0.877 & $93.7 \pm 1.2$ \\
\hline LMWF & 31.6 & 39.4 & 230 & 136 & 0.901 & $55.8 \pm 3.2$ \\
\hline
\end{tabular}

[Extract]: extract concentration; $\mathrm{f}_{\max }:$ frequency in which the imaginary component of the impedance is maximal; $\mathrm{R}_{\mathrm{p}}$ : polarization resistance; $\mathrm{Y}_{0}:$ magnitude of CPE; $\mathrm{C}_{\mathrm{dl}}$ : double layer capacitance; $\mathrm{n}$ : deviation from the ideal behavior; IE: inhibition efficiency; $\mathrm{SD}_{\mathrm{IE}}$ : standard deviation; HMWF: high molecular weight fraction; LMWF: low molecular weight fraction.

the electric double-layer structure, implying an adsorption phenomenon of the extracts molecules at the metal/solution interface.

LMWF also showed inhibitory action towards the mild steel acidic corrosion, but with lower inhibition efficiency $(55.8 \%)$. In general, for adsorption inhibitors, as the concentration increases, the metal active area available for corrosive reaction is decreased, raising $\mathrm{R}_{\mathrm{P}}$ and reducing $\mathrm{C}_{\mathrm{dl} \cdot}{ }^{6}$ We suggest then that the molecules responsible for the corrosion inhibition by the aqueous castor beans extract are present in the high molecular weight fraction, as the macromolecules.

Similarly, Figure 6 shows the Bode diagrams for the uninhibited and inhibited assays.

As discussed for the Nyquist diagrams, the addition of extract to the medium results in an increase of phase angles (Figure 6a) and impedance module (Figure 6b) in Bode's plots compared to the blank assay. Throughout the frequency domain analyzed, the diagrams presented a single

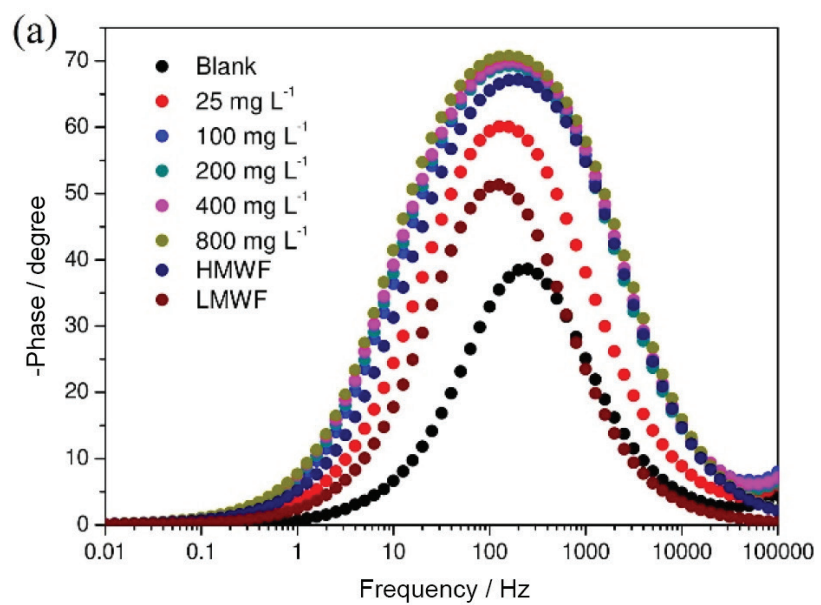

time constant in the 1000-10 Hz region, associated with the charge transfer process showing one maxima in bode plots. In the phase diagram (Figure 6a), a displacement of the maximum phase angle for lower frequencies indicates the change in the kinetics of the corrosive process in the presence of extract molecules.

\section{Potentiodynamic polarization curves}

Figure 7 shows the polarization curves of mild steel in $1 \mathrm{M} \mathrm{HCl}$ solution, in the absence and presence of ATE at 25, $100,200,400,800 \mathrm{mg} \mathrm{L}^{-1}$ and at $200 \mathrm{mg} \mathrm{L}^{-1}$ of HMWF and LMWF. Table 7 features the kinetic parameters extracted using the Tafel extrapolation method.

Figure 7 shows that the presence of ATE regardless of its concentration causes the decrease of the current densities of both branches, which is more explicit for the cathodic branch.

The increase in the concentration of ATE resulted in a decrease of the current density, when compared to

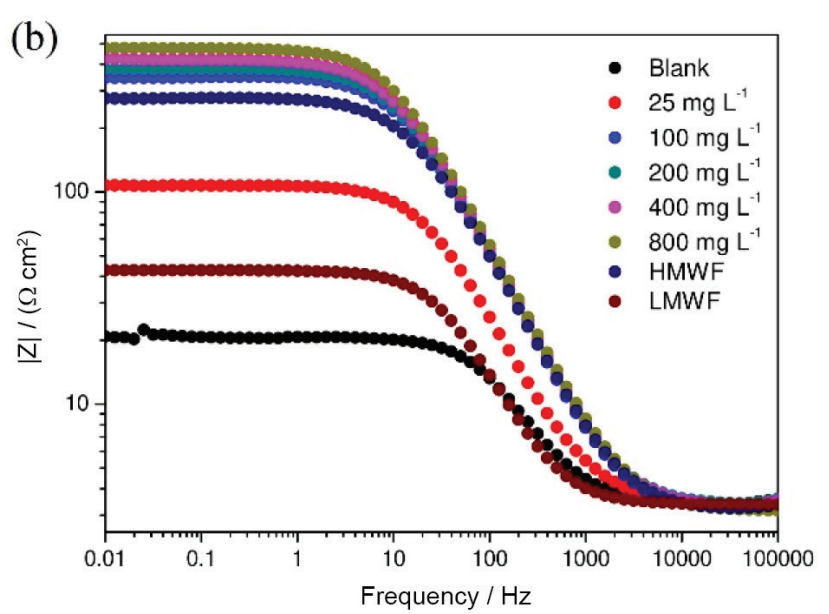

Figure 6. Bode plots for mild steel in $1 \mathrm{M} \mathrm{HCl}$ medium in the absence and presence of different concentrations of extract: (a) phase angle versus frequency and (b) impedance module versus frequency. 
Table 7. Kinetic parameters for mild steel in the absence and presence of castor beans extracts: ATE, HMWF and LMWF

\begin{tabular}{|c|c|c|c|c|c|c|}
\hline$\left[\right.$ Extract] / $\left(\mathrm{mg} \mathrm{L}^{-1}\right)$ & $\mathrm{E}_{\mathrm{OCP}} / \mathrm{mV}$ & $\mathrm{E}_{\text {corr }} / \mathrm{mV}$ & $\mathrm{j}_{\mathrm{corr}} /\left(\mathrm{mA} \mathrm{cm}^{-2}\right)$ & $-\beta_{\mathrm{c}} /\left(\mathrm{mV} \mathrm{dec} \mathrm{de}^{-1}\right)$ & $\beta_{\mathrm{a}} /\left(\mathrm{mV} \mathrm{dec}{ }^{-1}\right)$ & $\mathrm{IE} \pm \mathrm{SD}_{\mathrm{IE}} / \%$ \\
\hline 0 & -503 & -468 & $8.09 \times 10^{-1}$ & 128 & 77.2 & - \\
\hline 25 & -480 & -454 & $1.17 \times 10^{-1}$ & 115 & 68.4 & $85.5 \pm 3.2$ \\
\hline 100 & -495 & -482 & $4.06 \times 10^{-2}$ & 117 & 63.1 & $95.0 \pm 0.3$ \\
\hline 200 & -493 & -484 & $4.07 \times 10^{-2}$ & 119 & 67.6 & $95.0 \pm 0.3$ \\
\hline 400 & -492 & -484 & $3.54 \times 10^{-2}$ & 120 & 65.6 & $95.6 \pm 0.1$ \\
\hline 800 & -494 & -485 & $2.76 \times 10^{-2}$ & 118 & 60.5 & $96.6 \pm 0.4$ \\
\hline HMWF & -482 & -472 & $6.15 \times 10^{-2}$ & 121 & 70.0 & $92.4 \pm 0.3$ \\
\hline LMWF & -485 & -455 & $3.21 \times 10^{-1}$ & 133 & 81.2 & $60.3 \pm 0.5$ \\
\hline
\end{tabular}

[Extract]: extract concentration; $\mathrm{E}_{\mathrm{OCP}}$ : open-circuit potential; $\mathrm{E}_{\text {corr }}:$ corrosion potential; $\mathrm{j}_{\text {corr }}:$ corrosion current density; $\beta_{\mathrm{c}}:$ Tafel cathodic constant; $\beta_{\mathrm{a}}:$ Tafel anodic constant; IE: inhibition efficiency; $\mathrm{SD}_{\mathrm{IE}}$ : standard deviation; HMWF: high molecular weight fraction; LMWF: low molecular weight fraction.

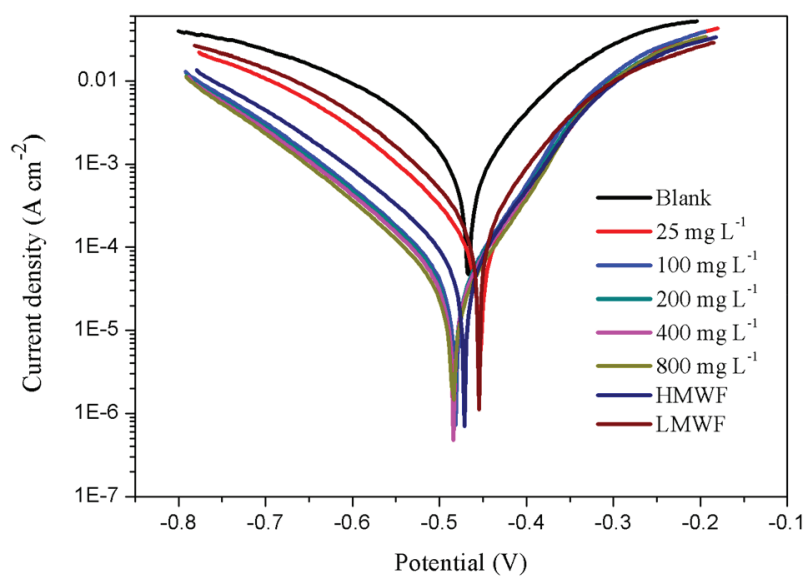

Figure 7. Potentiodynamic polarization curves for mild steel in the absence and presence of ATE, HMWF and LMWF.

blank, increasing the inhibition efficiency values and reaching a maximum IE value of $96.6 \%$ at $800 \mathrm{mg} \mathrm{L}^{-1}$ (Table 7), ratifying the previous discussion regarding the formation of the protective film. It is important to note that from $100 \mathrm{mg} \mathrm{L}^{-1}$ of ATE the IE increases very little for long immersion time (from $14440 \mathrm{~s}$ ). This behavior was observed by different assays (weight loss measurements, electrochemical impedance and polarization curves). $200 \mathrm{mg} \mathrm{L}^{-1} \mathrm{HMWF}$ presented an IE of $92.4 \%$ proving once again that the macromolecules are probably responsible to the inhibitory action of the extract.

The addition of ATE and its HMWF and LMWF displaced the OCP to more positive values with a maximum displacement of $+23 \mathrm{mV}$ for $25 \mathrm{mg} \mathrm{L}^{-1}$ of ATE. Moreover, it is observed that in ATE concentration of $25 \mathrm{mg} \mathrm{L}^{-1}$ and in the presence of LMWF, the $\mathrm{E}_{\text {corr }}$ was shifted to more positive values; while the others caused a shift to more negative potentials. The maximum displacements of $\mathrm{E}_{\text {corr }}$ were +14 and $-17 \mathrm{mV}$ for 25 and $800 \mathrm{mg} \mathrm{L}^{-1}$ ATE, respectively, which constitutes a mixed action of the extract. In general, the Tafel slopes for the anodic and cathodic reactions change very little with the addition of the inhibitors, which reflects in the small variation of the $\beta_{\mathrm{a}}$ and $\beta_{\mathrm{c}}$ constants. Since that the ATE addition showed a decrease of $E_{a}$, we can conclude that this extract acts as a mixed type inhibitor as the majority of organic compounds where the screening effect is added to the activation effect.

Corroborating with the electrochemical impedance results, the IE value for $200 \mathrm{mg} \mathrm{L}^{-1} \mathrm{HMWF}$ was $92.4 \%$, proving that the macromolecules are important in the inhibitory action of the extract.

\section{Linear polarization method}

Table 8 presents the polarization resistance values for ATE, HMWF and LMWF.

The polarization resistance of ATE increases with the extract concentration, reaching a maximum IE of $95 \%$ at $400 \mathrm{mg} \mathrm{L}^{-1}$. Once more, it is observed the high $\mathrm{R}_{\mathrm{p}}$ for HMWF, corroborating the important role of macromolecules in the inhibition process and the excellent performance of HMWF as a corrosion inhibitor for mild steel.

Table 8. Polarization resistance values for mild steel in $1 \mathrm{M} \mathrm{HCl}$ solution in the absence and presence of different concentrations of the total extract and its high and low molecular weight fractions

\begin{tabular}{lcc}
\hline Extract] $/\left(\mathrm{mg} \mathrm{L}^{-1}\right)$ & $\mathrm{R}_{\mathrm{P}} /\left(\Omega \mathrm{cm}^{2}\right)$ & $\mathrm{IE} \pm \mathrm{SD}_{\mathrm{IE}} / \%$ \\
\hline 0 & 21.6 & - \\
25 & 107 & $79.8 \pm 1.0$ \\
100 & 343 & $93.7 \pm 0.5$ \\
200 & 376 & $94.3 \pm 0.2$ \\
400 & 418 & $94.8 \pm 0.5$ \\
800 & 469 & $95.4 \pm 0.3$ \\
HMWF & 276 & $92.2 \pm 1.3$ \\
LMWF & 44.2 & $51.1 \pm 0.7$ \\
\hline
\end{tabular}

$\mathrm{R}_{\mathrm{P}}$ : polarization resistance; IE: inhibition efficiency; $\mathrm{SD}_{\mathrm{IE}}$ : standard deviation; HMWF: high molecular weight fraction; LMWF: low molecular weight fraction. 


\section{Adsorption isotherm}

In order to evaluate how the molecules of ATE interact with the metallic surface, four different adsorption isotherms models were tested: Langmuir, Temkin, Flory-Huggins and El-Awady. They relate the degree of surface coverage $(\theta)$ with the concentration of inhibitor, according to equations $7-10$, respectively. ${ }^{4}$ It should be noted that $\theta$ were calculated from the IE shown in Table 7 , following equation 11 .

$\frac{\mathrm{C}}{\theta}=\frac{1}{\mathrm{~K}}+\mathrm{C}$

$\theta=\left(\frac{-2.303}{2 \mathrm{a}}\right) \log \mathrm{K}+\left(\frac{-2.303}{2 \mathrm{a}}\right) \log \mathrm{C}$

$\log \left(\frac{\theta}{C}\right)=\log K+x \log (1-\theta)$

$\log \left(\frac{\theta}{1-\theta}\right)=\log \mathrm{K}+y \log \mathrm{C}$

$\theta=\frac{\mathrm{IE}}{100}$
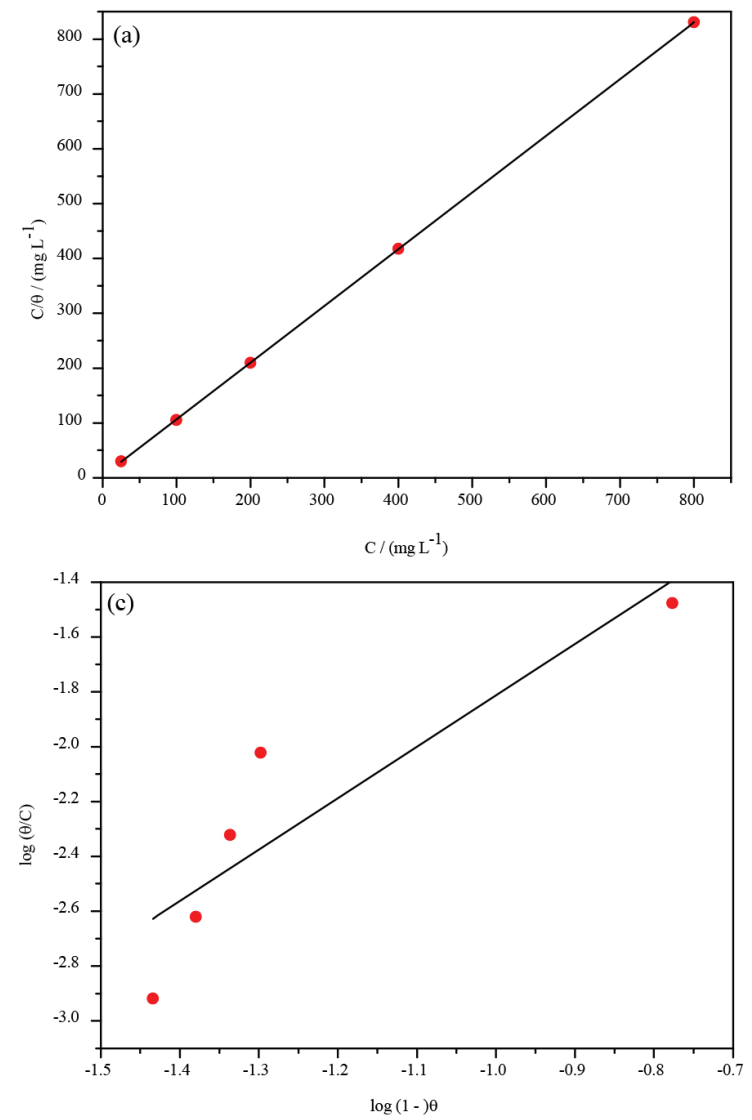

where, $\mathrm{C}$ is the concentration of inhibitor; $\mathrm{K}$ is the adsorption constant and $\mathrm{a}$ is the lateral interaction parameter between the adsorbed molecules.

Langmuir model (Figure 8a) assumes that the adsorption occurs at specific and homogeneous sites on the surface of the adsorbent, each site responsible for the adsorption of a single molecule. ${ }^{4}$ Although the good determination coefficient $\left(\mathrm{R}^{2}=0.998\right)$, shown in Table 9 , the angular coefficient deviated a little from one unit (1.03), allowing to suggest the interaction between adsorbed molecules of the inhibitor or the relation between active site for each adsorbed molecule different from one unit.,

Table 9. Data of straight lines obtained by linear adjustment

\begin{tabular}{lcc}
\hline Isotherm & Linear equation & $\mathrm{R}^{2}$ \\
\hline Langmuir & $y=1.03 x+3.09$ & 0.998 \\
Temkin & $y=0.0827 x+0.746$ & 0.661 \\
Flory-Huggins & $y=1.87 x+0.0619$ & 0.743 \\
El-Awady & $y=0.459 x+0.185$ & 0.759 \\
\hline
\end{tabular}

$\mathrm{R}^{2}$ : coefficient of determination.

Temkin model (equation 8, Figure 8b) postulates that the heat of adsorption decreases linearly as the covered surface increases. The interaction metal-inhibitor is
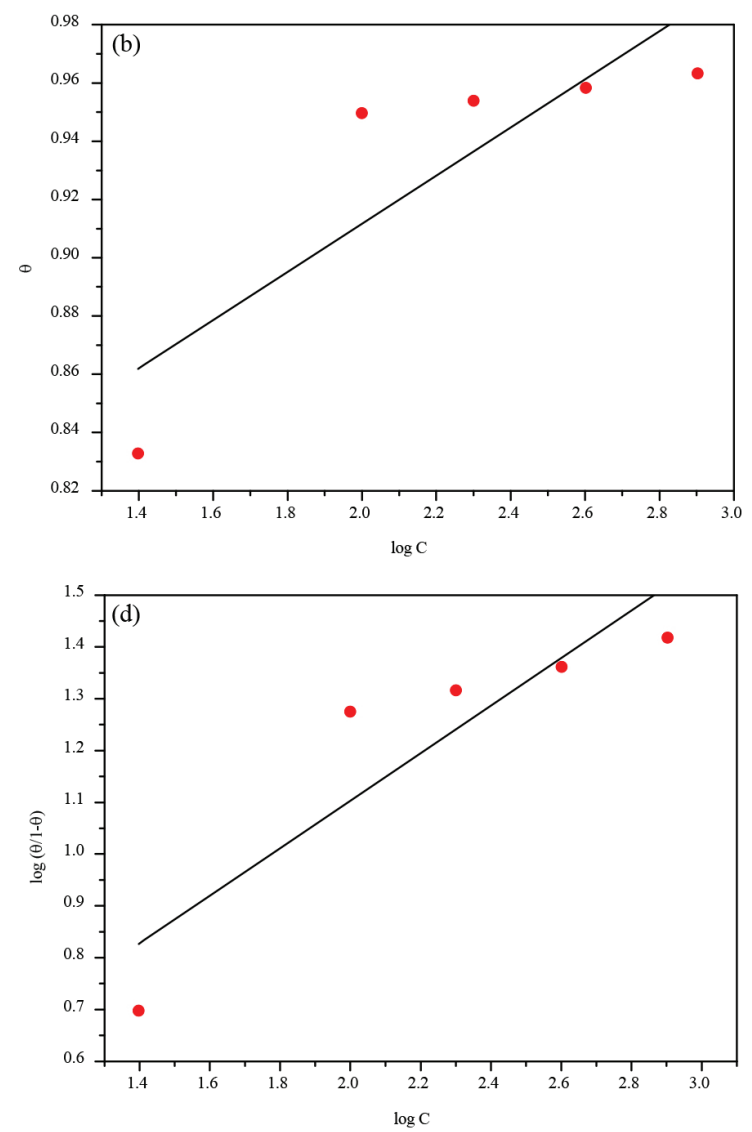

Figure 8. Adsorption isotherms of (a) Langmuir; (b) Temkin; (c) Flowry-Huggins and (d) El-Awady for ATE on mild steel surface in 1 M HCl solution. 
expressed by parameter a, which can admit positive values, indicating attraction, or negative, indicating repulsion. ${ }^{4}$ The parameter a for Figure $8 b$ is negative, indicating the repulsive nature of the interaction.

Flory-Huggins and El-Awady isotherms provide additional information. If the parameter $x$ of the first isotherm is greater than one unit, there is an indication that more than one molecule of water is displaced by a single molecule of the inhibitor. Similarly, if the parameter $y$ is less than one unit, it shows that a single molecule of the inhibitor may be adsorbed on more than one active site of the metal. ${ }^{4}$ The data seen in Table 9 shows that the displacement of water molecules by the extract ones occurs in a relation other than 1:1 and that one inhibitor molecule is adsorbed to more than one active site of the metal.

Although the determination coefficients of Figures 8b, $8 \mathrm{c}$ and $8 \mathrm{~d}$ are not as close to one as the Langmuir isotherm, their values can be considered satisfactory since they are between 0.60 and $0.99 .{ }^{4}$

\section{Surface analysis}

Figure 9 presents the mild steel surface in the absence of extract (Figure 9b), in the presence of $200 \mathrm{mg} \mathrm{L}^{-1}$ of ATE (Figure 9c) and $200 \mathrm{mg} \mathrm{L}^{-1}$ of HMWF (Figure 9d) for $2 \mathrm{~h}$ of immersion. Figure $9 \mathrm{a}$ shows the abraded surface of the mild steel, without acidic exposition.

When abraded, the mild steel surface evidences the polishing lines (Figure 9a). In the presence of only $\mathrm{HCl}$ solution (Figure 9b), it is possible to observe a high roughness related to the acid attack on the metallic surface. In the presence of $200 \mathrm{mg} \mathrm{L}^{-1}$ of ATE and HMWF (Figures 9c and 9d), the surface is much less rough and more uniform, showing the polishing lines as the ones observed in Figure 9a. Surface analyses ratify the weight loss measurements and the electrochemical results, which stated the effectiveness of ATE and HMWF to protect the surface of mild steel in $1 \mathrm{M} \mathrm{HCl}$.

\section{Chemical characterization}

\section{Energy dispersive spectroscopy (EDS)}

The chemical characterization of ATE and HMWF were performed by EDS, SDS-PAGE and FTIR. The mass percentages of the chemical elements found in EDS are in Table 10.

Table 10. Mass composition of the extracts in percentage

\begin{tabular}{lcc}
\hline \multirow{2}{*}{ Element } & \multicolumn{2}{c}{ Weight percentage / \% } \\
\cline { 2 - 3 } & ATE & HMWF \\
\hline Carbon & 51.6 & 51.2 \\
Oxygen & 34.3 & 22.0 \\
Nitrogen & 9.34 & 18.7 \\
Potassium & 3.30 & 7.85 \\
Sulfur & 1.31 & 0.143 \\
Magnesium & 0.104 & 0.0682 \\
\hline
\end{tabular}

ATE: aqueous total extract; HMWF: high molecular weight fraction.

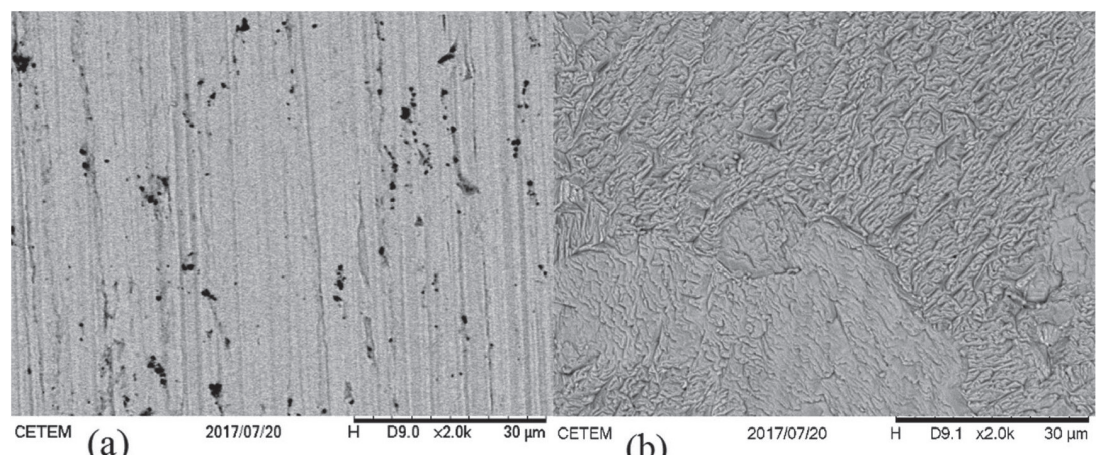

(b)

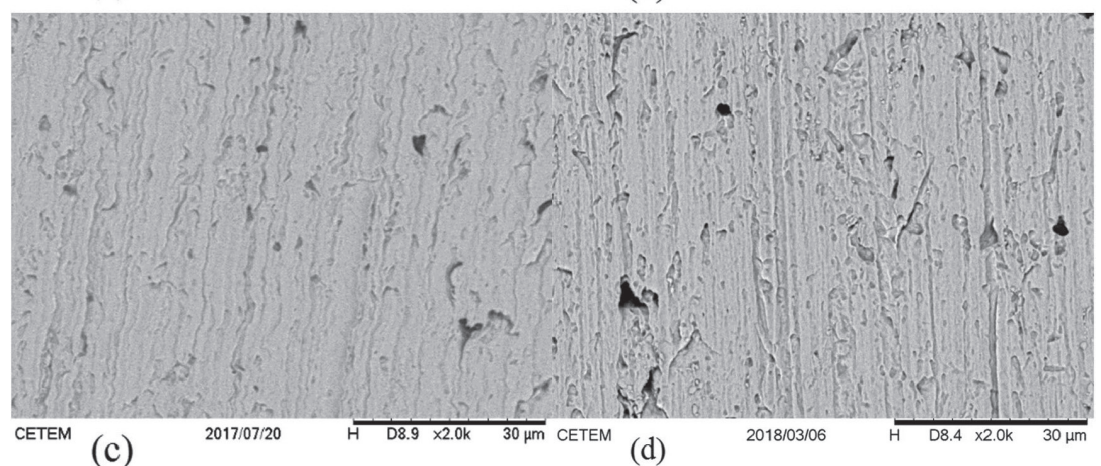

Figure 9. Surface micrographs of the mild steel of (a) the surface just abraded; (b) the surface after immersion in $1 \mathrm{M} \mathrm{HCl}$; (c) the surface after immersion in $1 \mathrm{M} \mathrm{HCl}$ containing ATE and (d) the surface after immersion in $1 \mathrm{M} \mathrm{HCl}$ containing HMWF. 
Table 10 indicates that the principal elements in the samples are carbon, oxygen and nitrogen, presented mostly in the structures of proteins, amino acids and alkaloids; corroborating with the discussion held so far. It can be seen a percentual enrichment of nitrogen in HMWF. In addition, both extracts exhibited sulfur in their composition, which may be related to the existence of cysteine and methionine, amino acids present in castor bean. ${ }^{48,49}$

\section{SDS-PAGE}

Literature ${ }^{24,50-52}$ approaches methods for detoxifying the co-product from the production of castor oil. The methods tested included autoclaving, steaming, fermentation, ionizing radiation and boiling, and others. Between them, it was shown that ricin could be efficiently inactivated by fermentation and treatment with $0.6 \%$ calcium oxide $(\mathrm{CaO})$, evaluated by cytotoxicity assays. According to de Souza et al..$^{35}$ the alkaline $\mathrm{pH}$ of $\mathrm{CaO}$ solution (around 12) affected the tertiary structure of ricin making the peptide bond more flexible, denaturing the polypeptide chains and eliminating its cytotoxic activity.

Figure 10 shows the protein profile of both extracts ATE and HMWF that were compared between themselves and with the purified ricin that appears around 32 and $34 \mathrm{kDa}$ in order to confirm the absence of ricin in HMWF. By these images (Figures 10a and 10b) we can observe that ATE clearly has ricin. Furthermore, the ricin could not be observed when HMWF was loaded with $10 \mu \mathrm{g}$ protein per lane (Figure 10a); nevertheless, it was present when $20 \mu \mathrm{g}$ protein was applied to the gel matrix (Figure 10b). This fact suggests that the quantity of ricin was too low in gel (Figure 10a) to be sensible to the analyses, which means that there was a decrease of the ricin content by the ultrafiltration process applied to obtain

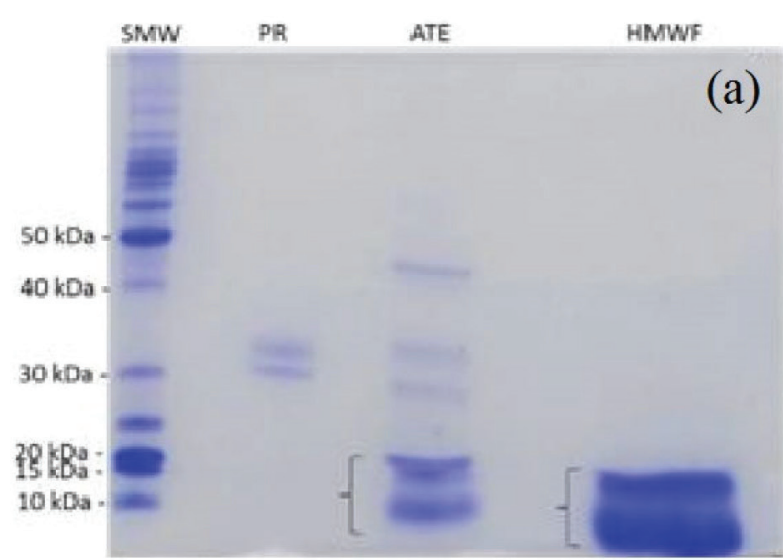

HMWF. This result has relevant importance as this is the first work that concerns about using methods to diminish ricin in the extract, decreasing environmental disturbances.

The ultrafiltration conserves a range from 3 to $50 \mathrm{kDa}$, as the protein ricin has from 62 to $66 \mathrm{kDa}$, probably a part of this ricin was already in the subunit form (32 and $34 \mathrm{kDa}$ ) when the extract passed by the membranes, justifying its presence in the gel (Figure 10b). Likely, one of the causes of this disaggregation was the extraction process, made with boiling water that can cause denaturation of the proteins.

Also, we can note that, as the loading was the same for the two samples analyzed (ATE and HMWF, Figure 10), the charge of protein with molecular weight below $15 \mathrm{kDa}$, highlighted by the curly brackets, were significantly bigger in the HMWF than the ATE (Figure 10a). This fact indicates that proteins below $15 \mathrm{kDa}$ were concentrated by the ultrafiltration process and could be the ones responsible for the inhibiting corrosion activity.

\section{FTIR spectroscopy}

FTIR spectra are illustrated in Figure 11.

Two significative absorption bands appear at 3433 and $3309 \mathrm{~cm}^{-1}$ that could be related to the stretching vibration of $\mathrm{N}-\mathrm{H}$ or O-H groups. Bands around $2900 \mathrm{~cm}^{-1}$ are indicative of symmetrical $\left(2927,2957 \mathrm{~cm}^{-1}\right)$ and asymmetrical $\left(2856 \mathrm{~cm}^{-1}\right)$ vibrations for $\mathrm{C}-\mathrm{H}$ groups. Furthermore, the absorption bands at 1745, 1658 and $1544 \mathrm{~cm}^{-1}$ could be associated to different stretching vibrations such as $\mathrm{C}=\mathrm{C}$, $\mathrm{C}=\mathrm{O}$ and $\mathrm{N}-\mathrm{H}$. Lastly, the absorption band at $1401 \mathrm{~cm}^{-1}$ might be related to $\mathrm{C}-\mathrm{H}$ bending vibration. ${ }^{5,7,16,53}$ All these results confirm the presence of protein in both extracts.

Thus, it can be stated that the natural inhibitors proposed in this work protect the surface of the mild steel against the

Figure 10. Chemical characterization of ATE and HMWF concerning the ricin. SDS-PAGE (12\%) of purified ricin and the extracts are carried out in the gels (a) and (b). Lanes: SMW, standard molecular-weight marker; PR, purified ricin ( 2 and $4 \mu \mathrm{g}$ protein (a) and $2 \mu \mathrm{g}$ protein (b)); ATE, aqueous total extract obtain from castor beans and HMWF, high molecular weight fraction obtained by the ultrafiltration of the ATE. For both samples it was applied to the lanes $10 \mu \mathrm{g}$ protein (a) and $20 \mu \mathrm{g}$ protein (b). All samples were treated with SDS and $\beta$-mercaptoethanol, and the gels were stained with Coomassie Brilliant Blue. (a) The curly brackets highlight the proteins below $15 \mathrm{kDa}$; (b) the arrows show the proteins that are present in both ATE and HMWF. 


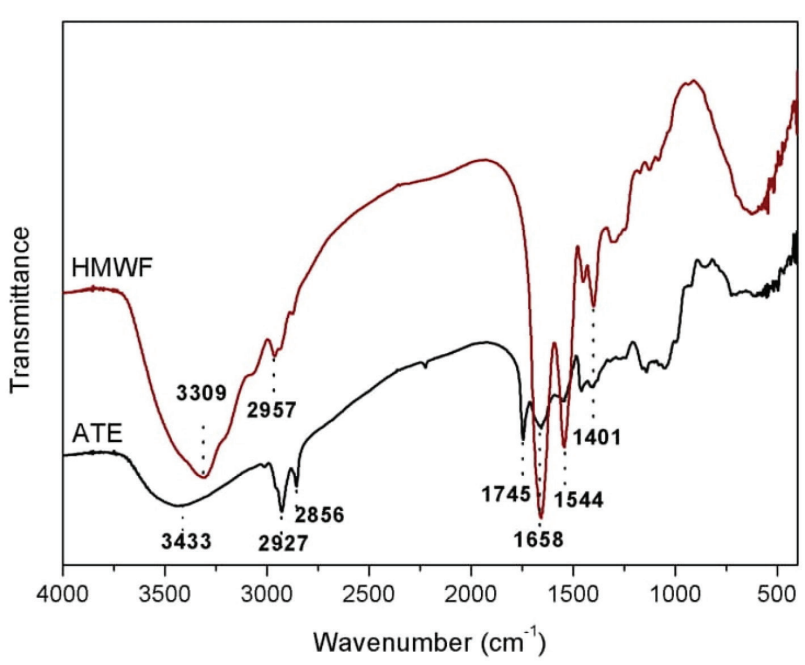

Figure 11. FTIR spectra (through a conventional $\mathrm{KBr}$ pellet technique) of ATE and HWMF.

corrosive activity of the acid medium. Many other natural inhibitors have been tested and reported in the literature as presented in Table 1. However, inhibitors from castor beans stand out for efficiencies above $90 \%$ using low concentrations (400 $\mathrm{mg} \mathrm{L}^{-1}$ ATE and $200 \mathrm{mg} \mathrm{L}^{-1} \mathrm{HMWF}$ showed IE of 95.8 and $93.7 \%$, respectively).

It is important to emphasize that, although ATE has given excellent results as a mild steel corrosion inhibitor in acidic medium, we should not use it directly due to the presence of ricin. The high molecular weight fraction, which can be obtained from castor cake, a residue of castor oil and biodiesel production, also presents excellent results as corrosion inhibitor.

\section{Conclusions}

ATE and HMWF presented excellent inhibitory action towards the mild steel corrosion in $1 \mathrm{M} \mathrm{HCl}$ solution. It was shown that the macromolecules have special participation in this process due to the high IE from HMWF. It was also observed that LMWF presented some inhibition, with IE around $50 \%$ in all electrochemical tests, which could be related to the existence of ricinoleic acid.

The Arrhenius plots demonstrated the chemical nature of the bond between the molecules of ATE and the mild steel surface. The inhibitor adsorption followed the Langmuir isotherm model, which admits the formation of a monolayer of the inhibitor molecules onto the metal surface.

The electrochemical impedance results indicated that the inhibitory molecules in both ATE and HMWF adsorb in the metal surface, modifying the electric double-layer structure. ATE acts as a mixed type inhibitor like the majority of organic compounds, where the screening effect is added to the activation effect.
The surface analyses showed that the aqueous castor bean extract and its HMWF acted as a good corrosion inhibitor, leaving the metal surface much less rough due to the adsorption of molecules, which retarded the corrosive process of the mild steel.

The chemical characterization indicated the presence of proteins in both ATE and HMWF, predominating the ones below $15 \mathrm{kDa}$ in the last one. This hints the probability of ricin having none or low influence in the corrosion inhibition and that these proteins $(<15 \mathrm{kDa})$ could be responsible for the inhibitory action towards the steel mild corrosion.

\section{Acknowledgments}

This work was supported by CNPq (National Council for Scientific and Technological Development, grant number 309353/2015-7 and 424306/2016).

\section{References}

1. Cordeiro, R. F. B.; Belati, A. J. S.; Perrone, D.; D’Elia, E.; J. Electrochem. Sci. 2018, 13, 12188.

2. Rodrigues, L. S.; Valle, A. F.; D’Elia, E.; Int. J. Electrochem. Sci. 2018, 13, 6169.

3. Matos, L. A. C.; Taborda, M. C.; Alves, G. J. T.; Cunha, M. T.; Banczek, E. P.; Oliveira, M. F.; D’Elia, E.; Rodrigues, P. R. P.; Int. J. Electrochem. Sci. 2018, 13, 1577.

4. Torres, V. V.; Cabral, G. B.; da Silva, A. C. G.; Ferreira, K. C. R.; D'Elia, E.; Quim. Nova 2016, 39, 423.

5. Hassannejad, H.; Nouri, A.; J. Mol. Liq. 2018, 254, 377.

6. Matos, L. A. C.; Rodrigues, P. R. P.; D’Elia, E.; Boschen, N.; Maia, G. A. R.; Cunha, M. T.; Taborda, M. C.; Abreu, C. C.; Banczek, E. P.; Rev. Propr. Ind. 2017, 1, 313.

7. Varvara, S.; Bostan, R.; Bobis, O.; Găină, L.; Popa, F.; Mena, V.; Souto, R. M.; Appl. Surf. Sci. 2017, 426, 1100.

8. Fernandes, C. M.; Fagundes, T. S. F.; Santos, N. E.; Rocha, T. S. M.; Garrett, R.; Borges, R. M.; Muricy, G.; Valverde, A. L.; Ponzio, E. A.; Electrochim. Acta 2018, 312, 137.

9. Satapathy, A. K.; Gunasekaran, S. C.; Sahoo, K. A.; Rodrigues, P. V.; Corros. Sci. 2009, 51, 2848.

10. da Rocha, J. C.; Gomes, J. A. C. P.; D’Elia, E.; Corros. Sci. 2010, 52, 2341.

11. Torres, V. V.; Amado, R. S.; de Sá, C. F.; Fernandez, T. L.; Riehl, C. A. S.; Torres, A. G.; D’Elia, E.; Corros. Sci. 2011, 53, 2385.

12. Mobin, M.; Basik, M.; Aslam, J.; Measurement 2019, 134, 595.

13. Abdulwahab, M.; Popoola, A. P. I.; Fayomi, O. S. I.; Int. J. Electrochem. Sci. 2012, 7, 11706.

14. Santos, A. M.; de Almeida, T. F.; Cotting, F.; Aoki, I. V.; de Melo, H. G.; Capelossi, V. R.; Mater. Res. 2017, 20, 492.

15. Trindade, R. S.; Santos, M. R.; Cordeiro, R. F. B.; D'Elia, E.; Green Chem. Lett. Rev. 2017, 10, 444. 
16. Li, X.; Deng, S.; Fu, H.; Corros. Sci. 2012, 62, 163.

17. Yaro, A. S.; Khadom, A. A.; Wael, R. K.; Alexandria Eng. J. 2013, 52, 129.

18. Odewunmi, N. A.; Umoren, S. A.; Gasem, Z. M.; Ganiyu, S. A.; Muhammad, Q.; J. Taiwan Inst. Chem. Eng. 2015, 51, 177.

19. El-Etre, Y.; Abdallah, M.; El-Tantawy, Z. E.; Corros. Sci. 2005, 47, 385.

20. da Rocha, J. C.; Gomes, A. C. P.; D’Elia, E.; Cruz, A. P. G.; Cabral, L. M. C.; Torres, A. G.; Monteiro, M. V. C.; Int. J. Electrochem. Sci. 2012, 7, 11941.

21. Okafor, P. C.; Ebenso, E. E.; Pigm. Resin Technol. 2007, 36, 134.

22. Pereira, S. S. A. A.; Pegas, M. M.; Fernandez, T. L.; Magalhaes, M.; Schontag, T. G.; Lago, D. C.; Senna, L. F.; D’Elia, E.; Corros. Sci. 2012, 65, 360.

23. Ibrahim, T. H.; Chehade, Y.; Zour, M. A.; Int. J. Electrochem. Sci. 2011, 6, 6542.

24. Saadawy, M.; Anti-Corros. Methods Mater. 2015, 5, 220.

25. Liao, L. L.; Mo, S.; Luo, H. Q.; Li, N. B.; J. Colloid Interface Sci. 2018, 520, 41.

26. Ferreira, K. C. R.; Cordeiro, R. F. B.; Nunes, J. C.; Orofino, H.; Magalhães, M.; Torres, A.; Int. J. Electrochem. Sci. 2016, $11,406$.

27. Beltrão, N. E. M.; de Oliveira, M. I. P.; Oleaginosas e seus Óleos: Vantagens e Desvantagens para Produção de Biodiesel, $1^{\text {st }}$ ed.; Embrapa Algodão: Campina Grande, Paraíba, Brazil, 2008.

28. Ramos, G. A.; Barros, M. A. L.; Cultivo da Mamona, $3^{\text {rd }}$ ed.; Embrapa Algodão: Campina Grande, Paraíba, Brazil, 2014.

29. Severino, L. S.; O que Sabemos sobre a Torta da Mamona, $1^{\text {st }}$ ed.; Embrapa Algodão: Campina Grande, Paraíba, Brazil, 2005.

30. Machado, C. G.; Martins, C. C.; Cruz, S. C. S.; Nakagawa, J.; Pereira, F. R. S.; Semina: Cienc. Agrar. 2010, 31, 301.

31. Sathiyanathan, R. A. L.; Maruthamuthu, S.; Selvanayagam, M.; Mohanan, S.; Palaniswamy, N.; Indian J. Chem. Technol. 2005, $12,356$.

32. Audi, J.; Belson, M.; Patel, M.; Shier, J.; Osterloh, J.; JAMA 2005, 294, 2342.

33. Thorpe, S. C.; Kemeny, D. M.; Panzani, R. C.; Mcgurl, B.; Lord, M.; J. Allergy Clin. Immunol. 1988, 82, 67.

34. Rao, P. V. L.; Jayaraj, R.; Bhaskar, A. S. B.; Kumar, O.; Bhattacharya, R.; Saxena, P.; Biochem. Pharmacol. 2005, 69, 855.

35. de Souza, L. M.; de Carvalho, L. P.; Araújo, J. S.; de Melo, E. J. T.; Machado, O. L. T.; Int. J. Biol. Macromol. 2018, 113, 821.
36. ASTM G31-7: Standard Guide for Laboratory Immersion Corrosion Testing of Metals; ASTM International, West Conshohocken, PA, 2013.

37. ASTM G59: Standard Test Method for Conducting Potentiodynamic Polarization Resistance Measurements; ASTM International, West Conshohocken, PA, 1997.

38. Anandan, S.; Kumar, G. K. A.; Ghosh, J.; Ramachandra, K. S.; Anim. Feed Sci. Technol. 2005, 120, 159.

39. Bradford, M. M.; Anal. Biochem. 1976, 72, 248.

40. Laemmli, U. K.; Nature 1970, 227, 680.

41. Massart, D. L.; Vandeginste, B. G. M.; Buydens, L. M. C.; Jong, S. D.; Lewi, P. J.; Smeyers-Verbeke, J.; Handbook of Chemometrics and Qualimetrics: Part A, $1^{\text {st }}$ ed.; Elsevier: New York, USA, 1997.

42. Akalezi, C. O.; Ogukwe, C. E.; Ejele, E. A.; Oguzie, E. E.; Int. J. Corros. Scale Inhib. 2016, 5, 132.

43. Zhang, Q.; Hua, Y.; Mater. Chem. Phys. 2010, 119, 57.

44. Amin, M. A.; Ahmed, M. A.; Arida, H. A.; Kandemirli, F.; Saracoglu, M.; Arslan, T.; Bararan, M. A.; Corros. Sci. 2011, $53,1895$.

45. Rosliza, R.; Senin, H. B.; Nik, W. B. W.; Colloids Surf., A 2008 , 312, 185.

46. Kim, C.; Pyun, S.; Kim, J.; Electrochim. Acta 2003, 48, 3455.

47. Alexander, C. L.; Tribollet, B.; Orazem, M. E.; Electrochim. Acta 2016, 188, 566.

48. Beltrão, N. E. M.; de Oliveira, M. I. P.; Detoxicação e Aplicações da Torta de Mamona, $1^{\text {st }}$ ed.; Embrapa Algodão: Campina Grande, Paraíba, Brazil, 2009.

49. Fernandes, K. V.; Deus-de-Oliveira, N.; Godoy, M. G.; Guimarães, Z. A. S.; Nascimento, V. V.; de Melo, E. J. T.; Freire, D. M. G.; Dansa-Petrtski, M.; Machado, O. L. T.; Braz. J. Med. Biol. Res. 2012, 45, 1002.

50. Godoy, M. G.; Gutarra, M. L. E.; Maciel, F. M.; Felix, S. P.; Bevilaqua, J. V.; Machado, O. L. T.; Freire, D. M. G.; Enzyme Microb. Technol. 2009, 44, 307.

51. Barnes, D. J.; Baldwin, B. S.; Braasch, D. A.; Ind. Crops Prod. 2009, 29, 509.

52. Odewunmi, N. A.; Umoren, S. A.; Gasem, Z. M.; J. Environ. Chem. Eng. 2015, 3, 286.

53. Jia, G.; Anjumb, S.; Sundaramb, S.; Prakash, R.; Corros. Sci. 2015, 90, 107.
Submitted: July 8, 2019

Published online: January 23, 2020 